\title{
O sagrado contemporâneo do teatro
}

The contemporary sacred of the theater

Alexandre Silva Nunes ${ }^{1}$ 


\section{Resumo}

O presente artigo discute experiências e teorias do teatro moderno, à luz do problema do sagrado, elegendo a figura de Antonin Artaud como artista simbólico desse problema com o qual o teatro moderno e contemporâneo se depara. Para isso, faz uso especial da leitura de Jacques Derrida sobre o teatro da crueldade, aliada a uma abordagem transdisciplinar, inerente à problemática estudada. Parte do pressuposto de que os vínculos entre o teatro e a experiência do sagrado não são apenas um dado histórico relativo às origens antigas da arte teatral, mas podem ser entendidos como realidade também atual, desde que revisitemos nossas noções acerca dos conceitos de sagrado e espiritualidade. Visitando axiomas da filosofia e da arte teatral, sustenta a ideia de que, ainda hoje, e mesmo em contextos não religiosos, é possível discutir a vigência de uma realidade sagrada do teatro. Com isso, busca ampliar a noção de sagrado para além das religiões, amparando-se na possibilidade de ocorrência de uma experiência de transcendência na imanência, tal como a ideia de uma metafísica em ato, postulada por Artaud.

Palavras-Chave: Teatro; Sagrado; Mito; Antonin Artaud; Contemporaneidade.

\section{Abstract}

This paper discusses experiences and theories of the modern theater, in the light of the problem of the sacred, and selecting Antonin Artaud as symbolic artist of this problem that the modern and contemporary theater is faced. To that end, he uses especially the analyses of Jacques Derrida about the theatre of the cruelty, combined with a transdisciplinary approach, inherent in the problem studied. He assumes the presuppose that the ties between the theatre and the sacred experience isn't only a historic fact, relative to ancient origins of the theater art, but can be understood also as current reality, so long as our ideas about the concepts of sacred and spirituality are reviewed. Analyzing philosophic and theatrical axioms, this paper supports the idea that, still today, and also in not-religious context, its possible discuss the validity of a sacred reality of theatre. Thus, seeks to expand the concept of sacred beyond of the religions, based in the possibility of occurrence of an experience of transcendence within immanence, such as the idea of a metaphysic in act, postulated by Artaud.

Keywords: Theater; Sacred; Myth; Antonin Artaud; Contemporary.

ISSN: 1414.5731

E-ISSN: 2358.6958

${ }^{1}$ Prof. Dr. Docente Adjunto III da Escola de Música e Artes Cênicas da Universidade Federal de Goiás (UFG), Goiás, Brasil.

nunes.imaginal@gmail.com 
O problema da presença do sagrado no teatro, ou do teatro no sagrado, ecoa inevitavelmente um problema mais amplo, da relação do homem contemporâneo com o sagrado, do lugar e das formas como o sagrado se apresenta na cultura e de suas relações com o fenômeno da laicidade. Porque o teatro, no que tange ao assunto, é parte de um continente maior, que coloca em questão, propriamente, um dos assuntos mais pungentes, controversos e ambíguos do mundo contemporâneo. Este assunto assume variadas máscaras e se comporta com uma diversidade de formas, manifestando-se como problema aparentemente independente (e central) na psicologia, na antropologia, na filosofia, na física e também nas artes. No contexto artístico, o teatro é, possivelmente, uma das formas de expressão que se deparou com o problema do sagrado da forma mais contundente, ao longo de sua história, apresentando-o de modo extremamente agudo no decorrer do século XX e ainda nos dias de hoje.

Dada a amplitude do tema, este artigo irá se concentrar mais especificamente no problema da relação entre o teatro e o sagrado no contexto da teatralidade contemporânea. Mesmo assim, é inevitável examinar a questão sem a ocorrência de reverberações históricas e/ou sem transcender o território específico das artes da cena, dado que o contemporâneo relaciona-se com o histórico e que o problema é, ipsis litteris, de natureza transdisciplinar. Por outro lado, as discussões acerca das relações entre teatro e sagrado e/ou entre teatro e ritual/cerimonial, costumam fazer referência ou fundamentarem-se em aspectos relativos à ancestralidade, a realidades históricas do passado remoto ou a realidades cultural ou geograficamente distintas (e distantes) da nossa. Trata-se, muitas vezes, de evasivas que correspondem ao medo científico do problema, e é exatamente por esta razão que sua abordagem, do ponto de vista contemporâneo, torna-se fundamental: ela dificulta os recursos de fuga ao problema e os extravios de uma mistificação, que mormente nos impedem de encará -lo como problemática factual e atual, e não meramente como dado histórico acerca das origens imemoriais, imprecisas e halteres, em relação ao teatro que vivemos.

Como resultado de estudos ainda recentes, publiquei, (NUNES, 2012) há cerca de três anos, uma atualização/compilação dos resultados que obtive, alguns anos antes, durante os estudos relativos à pesquisa de doutoramento realizada na Universidade Federal da Bahia. Ali, na mesma linha de pensamento ora apresentado, parti do pressuposto de que os vínculos entre o teatro e a experiência do sagrado não são apenas um dado histórico, relativo às origens gregas, egípcias, africanas ou qualquer outra que seja da arte teatral, mas podem ser entendidos como uma realidade também atual, desde que revisitemos nossas noções acerca dos conceitos de sagrado e espiritualidade, abertos a uma mudança na visão que comumente temos sobre aquilo que julgamos entender.

Foi numa linha similar de pensamento que o estudioso de teatro Mark Olsen, por exemplo, chamou a atenção para os vínculos ainda vigentes entre teatro e espiritualidade num pequeno livro dedicado ao assunto:

$\mathrm{Na}$ antiguidade, $\mathrm{o}$ ator esteve abertamente vinculado aos processos espirituais. No Egito, na Grécia, na Pérsia, na Suméria e, virtualmente, em todas as religiões 
tribais xamanísticas, o trabalho do ator era sagrado e uma contribuição inquestionável para a elevação da alma. Isto permanece como uma potencialidade até hoje, sendo que apenas o seu vínculo foi obscurecido por uma série de fatores, não sendo, porém, o menor deles as noções errôneas sobre o que, atualmente, significa o trabalho espiritual (Olsen, 2004, p. 4).

Partindo de uma fundamentação na psicologia arquetípica, a investigação que venho desenvolvendo visitou, de forma transdisciplinar, alguns axiomas das ciências humanas e da arte teatral para sustentar a ideia de que, ainda hoje, e mesmo em contextos não religiosos, é possível discutir a vigência de uma realidade sagrada do teatro. Com isso, ela tem visado ampliar a noção de sagrado para além das religiões, amparando-se na possibilidade de ocorrência de uma experiência de transcendência na imanência, tal como postulam os pensadores do campo da fenomenologia. Dando sequência a esta análise, a pesquisa vem discutindo experiências e teorias modernas e contemporâneas do teatro, identificando nelas uma tendência para a busca de experiências de transcendência para além da divisão elementar entre sagrado e profano.

Este artigo apresentará uma atualização dos estudos da pesquisa mencionada, cuja continuidade dá-se no âmbito do LABORSATORI - Núcleo Multidisciplinar de Pesquisa nas Artes da Cena (Universidade Federal de Goiás - UFG), e do grupo de pesquisa ÍMAN - Imagem, Mito e Imaginário nas Artes da Cena, através do projeto "Mito e Imaginário nas Artes da Cena" com financiamento do CNPQ. Pretende-se revisitar as principais conclusões anteriormente obtidas e apresentar novas reflexões que, à época, não puderam ser realizadas, optando por eleger a figura de Antonin Artaud como referencial para pensar sobre as transformações do teatro contemporâneo, em suas relações com o debate sobre o teatro e o sagrado. Esta seleção não pretende reduzir a complexidade do problema à figura de um único artista, mas utiliza-o como parâmetro simbólico das implicações que o tema levanta.

\section{Teatro e Sagrado}

Os debates em torno do sagrado e da religião têm se tornado cada vez mais comuns, e isso ocorre paradoxalmente de modo concomitante ao crescimento da laicização. Neste panorama, ganham mais proeminência as religiões dos povos chamados arcaicos e/ou primitivos, bem como os costumes rituais de civilizações antigas, que se encontram em desuso na vida do homem de hoje. O mesmo vale para o teatro ocidental, o qual, geralmente, recebe mais facilmente as contribuições rituais de povos distantes (no tempo ou espaço) que as de sua própria e atual cultura. Com certa frequência, esquece-se do próprio caráter ritual e metafórico do cristianismo, enquanto religião predominante de nossa cultura, assim como se esquece que suas bases cosmológicas não diferem tanto das de outras cosmogonias, guardando certos parentescos os quais podemos chamar de arquetípicos.

$\mathrm{Na}$ cultura de massa, a tensão paradoxal entre o ressurgimento do sagrado e a crescente laicização costuma equacionar-se através de uma espécie de popularização/pasteurização de ideias científicas, muitas vezes disseminadas de forma equivocada e prenhe de fantasias inconscientemente metafóricas. É como se a chamada ficção científica ajudasse a equilibrar a polarização entre um ainda crescente racio- 
nalismo e o desejo inconsciente de "mistérios" que legitima a ansiedade humana em relação à transitoriedade da vida e aos possíveis sentidos que ela pode resguardar. Como dizia Platão, todo filosofar é um filosofar sobre a morte e, num território arriscado e incerto como o da morte, o chão firme e seguro de uma ideia de ciência mostra-se capaz de disfarçar adequadamente nossa necessidade de imaginação simbólica. Ajuda a acalmar as inquietações sem abalar demasiadamente a noção de realidade vigente.

Real é um termo quase sempre empregado para elevar ou designar um status superior, como é o caso da realeza, mesmo que seu emprego entre em contradição com a realidade vigente. É um conceito de força e de referência para qualquer cultura, ainda que muitas vezes seja usado de forma contraditória. Para o homem comum, o real pode parecer se contrapor ao imaginário, o que se mostra muito distinto do conceito de real que baliza os povos que mantêm ainda uma vivência do sagrado em seu cotidiano, assim como a própria noção de realidade que a ciência contemporânea vem forjando com base em suas elaborações mais recentes. Mircea Eliade, estudando o sagrado e o profano, demonstra como o conceito de Real, em diversas culturas, pode referir-se a uma realidade superior à cotidiana; que é origem e causa da realidade ordinária (Eliade, 1992). Deste ponto de vista, realidade e imaginação não se contrapõem, mas se refletem como espéculos mútuos.

O teatro também começa sempre na experiência de uma fusão entre o real e o imaginário. Daí sua proximidade com a linguagem poética do mito. Através dessa fusão, entre a dimensão factual e a latência metafórica da imaginação, ele nos ajuda a refletir sobre o que há de mito em nossas ideias acerca do real, e o que há de realidade no imaginário social que partilhamos. E assim também nos ajuda a tornar conscientes mitos que cultuamos sem saber.

Um exemplo clássico que venho citando, no que tange ao tema, é a própria mitificação histórica da origem do teatro, a qual carrega como pano de fundo arquetípico os clássicos mitos de origem (ad perpetuam rei memoriam), alçando um cidadão grego, denominado Téspis, ao status de herói fundador de nosso reino teatral. Também personagens clássicos da historiografia oficial tendem a adquirir status mítico, sem que tomemos consciência. Isso ocorre independentemente de nossa vontade, sempre que tendemos a repetir determinadas ideias, reforçando-as, tais quais os rituais reforçam mitos. Assim, um Aristóteles mítico é reforçado sob a metáfora do pensador materialista, assim como um Ésquilo mítico se reforça sob a metáfora do demiurgo do teatro ocidental; decerto um mito similar ao do proto-ator Téspis, respondendo ditirambos.

\section{Mito e Realidade}

As relações entre mito e realidade, assim como os fundamentos desta última e da representação simbólica, costumam se confundir entre si, embora de forma nem sempre perceptível. Foi assim que a ideia de origem do teatro na Hélade foi aceita durante muito tempo, sem que sua relatividade pudesse vir a ser apreciada. De modo inverso, no entanto, as bases míticas desta mesma experiência teatral, não tiveram a mesma sorte. De modo que o mito de nascimento de Dioniso e o mito de origem do 
teatro, ambos na Grécia, foram sempre e confortavelmente distinguidos, um como narrativa fantasiosa, produto de uma mentalidade primitiva, e outro como narrativa objetiva, produto dos esforços de conhecimento científico. Apesar de haver, de fato, distinções entre o estatuto da ficção e o da realidade objetiva, atualmente podemos compreender que tanto as histórias de que se tem conhecimento acerca da origem do homem, quanto as narrativas de origem do teatro, têm validade sempre relativa, enquanto produtos de construção racional e imaginativa, em colaboração.

Em termos psicológicos, isso pode ser expresso na ideia de que o arquétipo provê as bases para que a história possa acontecer, enquanto produção da psique. É este o fundamento que o principal expoente do movimento da psicologia arquetípica, pós-junguiana, James Hillman apresentou ao analisar as linhas de relação entre mito e história:

$\mathrm{O}$ arquétipo provê as bases para a união desses incomensuráveis, fato e significado. Fatos históricos externos estão arquetipicamente ordenados de forma que revelem significados psicológicos essenciais. Essas ordenações arquetípicas de fatos históricos são os eternamente recorrentes mitemas da história e também de nossas almas individuais. Através desses significados a história atinge nossa psique, enquanto ao mesmo tempo a história é o palco no qual representamos os mitemas de nossa alma (Hillman, 1998, p. 17).

Numa época em que os rituais voltam a interessar aos homens de teatro e em que aproximações entre arte e vida são solicitadas e experimentadas com frequência, é natural que se volte também a indagar sobre as relações vigentes entre o teatro e o sagrado. O ponto de vista aqui defendido é o de que essa relação tem caráter essencial, ou seja, de que o teatro possui relação constituinte com as experiências do sagrado. E os índices imediatos de referência estão presentes na própria contemporaneidade, mais especificamente porque o movimento artístico contemporâneo tem apresentado experiências cênicas cuja eficácia nos leva a questionar os limites do artístico, suas conexões e seu alargamento de fronteiras com experiências de epifania. Isso é bastante perceptível em algumas experiências de arte performance, que buscam aproximações com o xamanismo entre outras operações místicas, mas não se limita a ela, se estendendo a outras formas de expressão teatral.

De modo bastante curioso, nossa modernidade apresenta duas facetas. De um lado, surge nela, de forma cada vez mais vertiginosa, o decreto da falência religiosa. De outro, cresce notavelmente o interesse por práticas esotéricas, atividades de meditação e interesse para com o pensamento mítico de diversos povos, halteres em relação a nossa cultura. É neste mesmo cenário que irrompem novos interesses pela atmosfera mítica e ritual da cena teatral, em termos de linguagem, processos de formação, feitura e recepção. Para melhor refletir sobre este status paradoxal da realidade em que estamos inseridos, passarei a analisar, nas próximas páginas, noções elementares acerca do mito, em suas relações diretas com a experiência cênica, a partir do que será possível observar o modo de funcionamento da noção de duplo no teatro.

Quando afirmo que o teatro começa sempre na experiência de uma fusão entre o real e o imaginário, refiro-me a sua capacidade de nos ajudar a refletir sobre mitos 
conhecidos e a tornar conscientes mitos que não sabemos que cultuamos, o que nos ajuda a precisar o lugar onde se situa esse vínculo que reúne teatro e sagrado. Diria que esse lugar é o da interseção entre aquilo que podemos designar como ordinário e aquilo que é extraordinário; que também é o lugar de encontro entre fato e significado, na linguagem arquetípica. Porque, no teatro, as fronteiras entre estes campos de realidade e imaginação são necessariamente tênues, gerando confusão entre metáfora e literalidade, da qual irrompe toda experiência cênica. É aí que pode acontecer o prestígio de um ato que não está voltado a sua função objetiva, encontrada no cotidiano, mas que pode estranhar e questionar (Brecht), reforçar ou restaurar (é o caso de toda ação ritual) o sentido do ato cotidiano.

Assim, podemos encontrar o sentido de sagrado do teatro, mesmo em lugares onde não o esperaríamos, levados que somos por nossos vícios do pensamento. $E$ assim podemos discutir um sentido de sagrado inclusivo e que não dispensa a capacidade de pensamento, em favor daquilo que suplanta o pensamento. O que também autoriza-nos discutir aproximações entre teatro e sagrado, inclusive do ponto de vista de um ateísmo potencial, vencendo uma das maiores barreiras que o pensamento dual nos legou, e que forçosamente limita os horizontes de desenvolvimento do pensamento humano.

Isto quer dizer que o lugar do sagrado não precisa ser exatamente um lugar "reservado", nem muito menos indiferente ao que se pode designar de ordinário. De forma quase contrária, diríamos que o lugar do sagrado no teatro é exatamente o da relação com o que há de rotineiro na vida humana, lugar onde o ordinário, o cotidiano e o trivial podem reencontrar suas razões, e onde cisões com a tradição podem ser instauradas, diante da insurgência extraordinária de novas realidades. $O$ fato de caminhar lado a lado com o mito dá ao teatro a impossibilidade de desvincular-se do sagrado. Nele, mais que em qualquer outra arte, o imaginário precisa ser instaurado no (e enformar o) próprio cotidiano "profano".

Como explicou Eliade, na vida dos povos arcaicos e tradicionais, todas as atividades humanas mantêm uma conexão com fundamentos de ordem sagrada. Assim, as ações desempenhadas na caça, na pesca, no cultivo do solo, e em quaisquer atividades técnicas ou mesmo rituais, possuem uma mitologia que thes serve de fundamento. Em tais construções míticas ocorre invariavelmente a presença de um herói fundador, ou de um deus que, in illo tempore, defrontou-se pela primeira vez com a circunstância que gerou a origem daquilo que o mito em questão trata, vindo a se tornar modelo de referência. Trata-se sempre de um modelo de ação a ser seguido, um tipo de comportamento capaz de a todos orientar: "devemos fazer o que os deuses fizeram no princípio" (excerto literal da tradição brâmane, in Eliade, 2004, p. 12). É neste ponto que podemos vislumbrar uma intercessão entre a realidade ordinária e aquilo que pertence ao domínio atemporal na topologia do sagrado, e no qual podemos identificar faculdades cênicas inerentes às noções de ação mítica:

A principal função do mito consiste em revelar os modelos exemplares de todos os ritos e atividades humanas significativas: tanto a alimentação ou o casamento, quanto o trabalho, a educação, a arte ou a sabedoria. (Eliade, 2004, p. 13) 
A apropriação de valorações míticas com proveito artístico não é exatamente um dado novo. Ela é intrínseca a todas as histórias sobre origem que assinalam os rituais sagrados de tempos e lugares primevos como ancestrais comuns à celebração religiosa e ao teatro. Donde podemos considerar o ato cênico como correlato do ato mítico, sempre atualizado pelo rito, e a chamada ação física, stricto sensu, como ação ritual, ou seja, ação concreta plena de motivos imaginais.

A este artigo não importa o conteúdo, em si, da proposição clássica das origens do teatro, mas observar o conteúdo mítico que lhe é intrínseco. Como necessidade arquetípica de apontar nossos diálogos primordiais com o numinoso como sempiternos progenitores do espetáculo cênico. O que implica dizer que o teatro, tal qual o deus grego que lhe é patrono, tem origem estranha, estrangeira, vem de outro mundo, como se dizia que Dioniso é deus estrangeiro. E que o teatro é um alter-ego da realidade concreta, um duplo ou sombra que nos conecta com nossas raízes ou que nos cobra o esquecimento delas, como poetizou Artaud.

\section{O teatro e o sagrado no contemporâneo}

As possibilidades de dedução que advêm das afirmações às quais chegamos acima podem ser sintetizadas em três sentenças, sendo a terceira a perspectiva com a qual estamos trabalhando: 1) o teatro nasceu de rituais sagrados, ou é o ritual sacro arcaico o ancestral comum do teatro e de nossos ritos religiosos atuais; 2) o teatro é mais uma das diversas possibilidades rituais (como nos estudos da performance); 3 ) teatro e ritual são possibilidades culturais com muitos caracteres em comum, e a conexão com o sagrado ocorre em ambas, de modos entretanto diferentes. Neste caso, pode o teatro mascarar sua relação com o sagrado, numa sociedade secular, através de procedimentos que disfarçam o poder simbólico de nossos gestos e verbos (nominalismo), atribuindo-lhes tão somente valores semânticos fechados a qualquer possibilidade de relação com o imaginal, com aquilo que se manifesta como haltere, em relação ao habitual de nossa vida, transcendendo os limites da capacidade humana de entendimento lógico/conceitual da realidade.

Esta terceira via de pensamento, apesar de partir de estudos relativos a sociedades arcaicas, em especial ao estudo da imaginação mítica, situa-se no horizonte possível de nossa contemporaneidade teatral. Como anunciado no início do artigo, nossa meta é exatamente discutir o sagrado do teatro sob uma perspectiva constituinte, que permita refletir sobre ele em nossa realidade atual, e não apenas como uma referência ao passado imemorial de origem, estabelecendo, contudo, distinções entre uma coisa e outra. Neste sentido, vale observar que o século XX foi, de modo muito especial, o momento histórico do teatro no qual a discussão sobre as origens ocorreu do modo mais marcante, denunciando o funcionamento de determinados mecanismos arquetípicos de fundo, que revelam a procura de uma reconexão da prática teatral com aquilo que lhe dá significado em nossa cultura.

Antes, porém, de entrar propriamente na discussão de algumas das grandes questões do teatro contemporâneo, será oportuno pôr em questão nossas ideias sobre o contemporâneo, observando que essas ponderações estéticas postas para discussão têm também uma pátria, uma origem, uma base cultural e mítica que lhes 
situam, ainda que se pretendam universais. É assim que podemos observar, inicialmente, que a noção de contemporâneo com a qual trabalhamos é uma ideia bastante ocidental, a qual reflete o modo europeu de pensar, ainda que sob a perspectiva de um país colonizado, como é o caso do Brasil. Do ponto de vista científico e cultural, somos parte desse grande continente imaginário ao qual dá-se o nome de Ocidente, ainda que a ele tenhamos agregado, de forma até mesmo involuntária, novos elementos e dispositivos de pensamento estanhos e estrangeiros. Também é importante observar que

tanto quanto o próprio Ocidente, o Oriente é uma ideia que tem uma história e uma tradição de pensamento, um imaginário e um vocabulário que lhe deram realidade e presença no e para o Ocidente (Said, 2007, p. 31).

Por outro lado, e na mesma esteira de pensamento, deve-se observar que "havia - e há - culturas e nações cuja localização a leste, e suas vidas, histórias e costumes têm uma realidade bruta obviamente maior que qualquer coisa que se poderia dizer a respeito no Ocidente" (Said, 2007, p. 32). O alerta de referência ao Ocidente é, portanto, uma alternativa ao mesmo tempo factual e ficcional, na qual coexistem dados de imaginação e de objetividade geográfica, o que entra em sintonia com as próprias ideias com as quais temos trabalhado. Especialmente no que se refere ao teatro, que precisou alimentar muito de suas fantasias sobre o Oriente, para autorizar uma reconsideração do que, no Ocidente, se entende por cultura.

No que pese, entretanto, aquilo que chamamos de cena contemporânea não pode ser entendida sob uma única noção, uma tendência estética central, em torno da qual se estruturam as diversas manifestações. E se for preciso, por insistência, pensar em alguma estética geral esta só poderia estar sob o signo ou ser propriamente o signo da pluralidade, da diversidade. Este é um ponto em torno do qual tem havido algum consenso na atualidade, visto que mesmo em termos de nomenclatura os acordos não estão próximos: seria legítimo falar em pós-modernidade? E, mesmo que seja, o que se pretende designar exatamente com um termo tão inócuo quanto este, um termo que não diz nada daquilo que pretende nomear, além de uma mera localização temporal: após o moderno?

Por curioso que seja, é exatamente nesta falta que identificamos uma característica peculiar acerca do imaginário artístico em que vivemos: Ele (ainda, tal qual a modernidade) aponta à frente. Ou mais, precisamente diz localizar-se não no agora, mas naquilo que está à frente, após. Se o termo moderno ressalta vínculo fundamental com a atualidade, com o presente vivido, e certo desprezo em relação ao passado, o termo pós-moderno associado ao momento atual informa que o presente é futuro, que o atual presente se localiza objetivamente após ele, além dele mesmo, ou que o momento presente não é atual, mas avançado em relação à própria noção de avanço. De modo que o termo suscita reminiscências inevitavelmente míticas: tanto quanto o momento ab-origine referenciado pelas narrativas míticas (Eliade) influi sobre a vida corrente presente, sendo distinto dela, o estado de devir, a condição de porvir, de habitar o que virá a ser, ou de estar no vazio, mas já sob o jugo daquilo que está por vir, valora o momento presente com apoio numa vaga ideia de futuro. Mesmo que 
os vetores sejam distintos, num e noutro caso, ou indiquem sentidos contrários, eles têm conotação similar: buscam os sentidos daquilo que se faz através da conexão com fundamentos atemporais, in illo tempore.

E esta constatação, em si, já agrega um outro dado na investigação que fazemos sobre o lugar do sagrado no teatro atual: ele não é visível apenas no interesse objetivo por rituais, pelas tradições cênicas indianas, japonesas ou balinesas, pelas festas populares ou manifestações culturais de matriz africana, também despreocupados em diferir onde começa a arte e onde termina o rito. Este fundamento, como podemos entrever, a partir da perspectiva de Eliade, é devedor da necessidade de vínculo entre o real ordinário e o Real imaginal, extraordinário, comumente referido pela ideia simbólica de uma cena da origem. Seguindo o fluxo de um mesmo movimento, a própria necessidade (pós)moderna de se fixar em ideias de futuro, no rompimento e criação de novos paradigmas, criação de novas formas e modelos, denuncia uma base arquetípica operando com aquilo que suplanta o lugar e o momento presente, para colocá-lo em relação com o que está presente no cotidiano, suplantando-o.

\section{O sagrado atual do teatro, ou o teatro segundo Artaud}

As aproximações entre o teatro e o sagrado já foram bastante observadas na obra de Antonin Artaud. Neste sentido, é oportuno lembrar que o anterior interesse da alquimia pelo teatro, e vice-versa, foi oportunamente assinalado pelo encenador -ator francês através de uma equiparação entre a alquimia e as faculdades mágicas da cena, que opera através da construção de miragens, alterações sensíveis da realidade, sobreposição de realidades imaginais:

Todos os verdadeiros alquimistas sabem que o símbolo alquímico é uma miragem assim como o teatro é uma miragem. E esta perpétua alusão às coisas e ao princípio do teatro que se encontra em quase todos os livros alquímicos deve ser entendida como o sentimento [...] da identidade que existe entre o plano no qual evoluem as personagens, os objetos, as imagens, e de um modo geral tudo o que constitui a realidade virtual do teatro, e o plano puramente suposto e ilusório no qual evoluem os símbolos da alquimia (Artaud, 1993, p. 43).

$\mathrm{Na}$ perspectiva deste vínculo indicado por Artaud, a riqueza da imagética alquímica pode se revelar como índice de referência para a criação teatral, podendo fornecer inúmeras ideias simbólicas propícias a um pensar por imagens. O paralelismo indicado por Artaud, entre o teatro e a alquimia, acorda-nos também para o fato de que o teatro, apesar de lidar com materiais concretos e se inscrever na realidade imediata de nosso tempo-espaço, mantém-se vinculado a outra dimensão da realidade, tal como o trabalho realizado pelos alquimistas. Esta dimensão funcionaria como reflexo ou sombra, de modo similar à forma como a psicoterapia de base corporal, oriunda dos estudos abertos por Wilhelm Reich, e desenvolvidos por Alexander Lowen, Stanley Keleman e John Pierrakos, vislumbra a ocorrência de correspondências diretas entre psyche e pshysis, identificando mitos encrustados na estrutura muscular do caráter. Deste ponto de vista, não apenas a fricção de fantasias produz mudanças no corpo, como mudanças na dramaturgia corporal produzem alterações no modo de viver e fantasiar. 
Controverso tanto naquilo que pensou e produziu artisticamente quanto no curso da própria vida, Artaud veio a se tornar mister em desorganizar as coisas, explodir conceitos e, especialmente, cultivar o grito como princípio filosófico para a reinvenção da cultura. O grito de Artaud, ademais, não tinha conotação apenas filosófica ou artística, mas resultava igualmente de uma demanda pessoal: a de se ver desapropriado da própria vida. E é nesta intersecção entre os aspectos artísticos e pessoais de sua atitude que identificamos uma das questões mais significativas das relações entre teatro e sagrado, por ele apresentada: a denúncia de que toda separação entre o pessoal e o profissional, na arte, não passa de uma construção artificial e perigosa, responsável por muitos dos prejuízos que o fazer artístico ocidental sofreu ao longo de sua história.

Este estabelecimento de uma linha divisória liminar ecoa até os dias de hoje, podendo nos acordar a qualquer momento de nossa demência e de nossa dormência frente ao imperativo de uma vida que, apenas em momentos de crise, como durante uma peste ou sob a força de um tsunami, nos é dado enxergar em sua pungência urgente. Mas o grito também possui outras virtudes na obra de Artaud, pois lhe serviu como norte de referência para pensar uma linguagem (simbólica e pulsional) situada num lócus anterior ao da linguagem conceitual. Uma linguagem ontologicamente anterior ao momento em que a palavra cristaliza ideias segundo as rédeas da razão. $\mathrm{E}$ apesar de manter suspeitas profundas para com a palavra escrita, ele legou uma extensa obra escrita, caracterizada especialmente pelas rupturas do pensamento; uma escrita que se ordena mediante síncopes e irrupções (cf. Felício, 1996).

A experiência do sagrado, em Artaud, vincula-se diretamente à experiência de vida do ser humano, mas não no sentido em que Constantin Stanislavski a considerava. Primeiro, porque o erro capital da tradição teatral do Ocidente, para Artaud, foi pretender que o teatro retratasse o homem ou o que ele faz (cf. Derrida, 2002, p. 152) no limiar de sua psicologia privada. Segundo, porque o individual só viria a ter importância, na economia do teatro da crueldade, em se tratando do modo como o ator, enquanto indivíduo e artista, poderia (re)construir sua existência corporal concreta, com vistas a penetrar o núcleo da vida, do humano enquanto experiência universal. Deste modo, a temática do humano vai interessar ao pensamento teatral de Artaud a partir de dois prismas opostos e complementares: 1) denúncia de uma construção do humano sustentada nas categorias da razão, da ordem, da moral e da palavra enquanto centro de irradiação do pensamento conceitual; 2) necessidade de reconstrução do humano, considerando gravemente sua realidade pulsional, corporal, trágica e cruel; a partir daquilo que é da ordem da vida vivida, e não das abstrações de essência. Fundindo sempre aquilo que concerne à vida e aquilo que diz respeito à arte, os caminhos por ele apontados para a reconstrução do teatro implicam irremediavelmente uma reorientação da noção de cultura e, nela, do ser humano:

O mais importante não me parece tanto defender uma cultura cuja existência nunca salvou qualquer ser humano de ter fome e da preocupação de viver melhor, mas extrair, daquilo que se chama cultura, ideias cuja força viva é idêntica à da fome. (Artaud, 1993, p. 1) É preciso acreditar num sentido da vida renovado pelo teatro, onde o homem impavidamente torna-se o senhor daquilo que ainda não é, e o faz nascer (Artaud, 1993, p. 7). 
Qual seria, portanto, a importância e o lugar do humano e do sagrado nesta reconstrução da noção de cultura e, igualmente, da criação de uma linguagem própria do teatro? Em primeiro lugar, cumpre observar que estes fatores encontramse profundamente encadeados no pensamento de Artaud. O lugar do humano não pode, sob qualquer hipótese, desvincular-se do sagrado, sob pena de afastar-se da pungência de sua realidade profunda, afogando-se inevitavelmente nos formalismos da linguagem conceitual e do primado da razão. O sagrado e a carne estão, portanto, inteiramente relacionados. A linguagem própria ao teatro, por consequência, é aquela que devolve o indivíduo a esta realidade tácita da qual faz parte, tenha-se consciência ou não. Tratar-se-á de uma linguagem que tem como referência os sonhos e os mitos. Uma linguagem também baseada nas pulsões do corpo, nas imagens e na simbólica dos gestos, capaz de permitir ao homem aquilo que a lógica dos conceitos, do desenvolvimento da razão linear de causa-efeito, jamais poderia atingir, e, sem o qual, somos assaltados pelo que Freud teria denominado de retorno do recalcado:

Todas as nossas idéias sobre a vida devem ser retomadas numa época em que nada adere mais à vida. E esta penosa cisão é a causa de as coisas se vingarem, e a poesia que não está mais em nós e que não conseguimos mais encontrar nas coisas reaparece de repente, pelo lado mau das coisas; nunca se viram tantos crimes, cuja gratuita estranheza só se explica por nossa impotência para possuir a vida. (Artaud, 1993, p. 3)

Na economia cênica que ele traça, aquilo que é da ordem da superfície no ser humano, ou seja, da ordem do puramente técnico e objetivo, não pode significar senão uma forma de amputação da totalidade do ser, uma forma de aleijar a vida. 0 homem, tomado isoladamente, não passa de uma marionete inconsciente das forças que o movem. Deste ponto de vista, Artaud vai, na verdade, muito além do meramente humano, para incluir e se concentrar nas forças que atuam no homem. Forças que estão inteiramente ligadas a sua noção de metafísica teatral, à transcendência que o teatro, segundo ele, é capaz de operar. Uma transcendência que não pode ocorrer sem que antes se processe a morte do homem, tal como ele foi cunhado pela cultura aleijada do Ocidente. Morte do homem que se vincula igualmente à morte do Deus do qual esse homem é corolário, ou vice-versa; morte do homem-deus mutilado pelo medo das pulsões de vida que o habitam. Morte também do stablishment social, das instituições de controle criadas e mantidas para impedir-nos de entrar e manter contato direto com a vida. Porque, para Artaud, o Deus do Ocidente é o principal responsável por essa separação dual, que nos mantém em constante cisão conosco e com o sagrado que, potencialmente, pode irromper a qualquer momento, caso venhamos a cavar em nós a abertura necessária a sua manifestação.

É esta a razão pela qual ele irá travar, de modo similar a Nietzsche, uma luta implacável contra o cristianismo, contra as ideias religiosas então dominantes na Europa, que satanizavam o corpo, regulavam a moral, separavam carne e espírito. Que estabeleciam a ordem de uma determinada lógica de vida (seria o caso de dizer, de não-vida, para ser fiel ao pensamento de Artaud). Porque sua crítica ao cristianismo se estende a todas as instituições de maneira geral. E percebe-se que se tratará exatamente da irrupção de uma revolta contra as heranças ainda vigentes da heteronomia, 
que alienam o sujeito e o despojam da autonomia sobre sua própria experiência de vida. Conforme observa Vera Lucia Felício, acerca do assunto:

Se existe o valor do mal, é porque a religião recusa a vida terrestre considerada como alguma coisa ligada ao mal e volta-se para uma felicidade além desta vida terrestre. Esta deve ser constituída por sacrifícios, sujeição aos sacerdotes e numa esperança de felicidade além-túmulo. A luta contra a noção de deus se dá, para Artaud, como uma luta contra uma falsa-palavra ou um falso-valor que bloqueia o espírito (Felício, 1996, p. 51).

Ou, nas palavras do próprio Artaud:

Pois longe de acreditar no sobrenatural, no divino, inventados pelo homem, penso que é a intervenção milenar do homem que acabou por nos corromper o divino (Artaud apud Derrida, 2002, p. 166).

Do ponto de vista objetivo da cena, a manutenção de relações estreitas entre o ser humano, o sagrado e a linguagem própria do teatro também terá consequências significativas. Neste sentido, é oportuno lembrar que Artaud rejeitava a definição de arte como imitação da vida (ou seja, do exterior dos fatos). Esta rejeição vai até seus limites mais radicais, de modo que toda e qualquer imitação, toda e qualquer tentativa de repetição, vem a se tornar, para ele, objeto de recusa: o ator não poderia e não deveria refazer duas vezes o mesmo gesto. Cada ação no teatro da crueldade precisaria ser absolutamente original, única. Daí, o ideal teatral de Artaud passa a ser o de que cada espetáculo só venha a ser apresentado, ou melhor, realizado/ritualizado, uma única vez, sob risco de, pela repetição, ele voltar a aprisionar o homem no acabado. Sob nova ameaça de morte do teatro: quando uma realidade viva insurge para, logo depois, ser capturada e assassinada pela repetição, que lhe exaure a pungência de origem.

Isto o faz caminhar no sentido oposto ao da noção de representação. Estando diretamente ligado à vida, o teatro deixa de ser representação (no sentido que comumente se dá ao termo) para poder vir a ser uma forma singular de expressão da vida, uma forma própria de exercer a vida. Como ele mesmo afirmou num de seus poemas: "Onde outros propõem obras eu não pretendo senão mostrar o meu espírito. [...] Não concebo uma obra isolada da vida" (Artaud, 1991, p. 13). Resta que, segundo preceitos como esse, não haveria nada a re-presentificar, mas apenas gestos e atos a serem produzidos. Capturar cenas em sua origem para, em seguida, esquecê-las sem a sombra de quaisquer formas de apego. A única possibilidade de acordo com a noção de representação se situaria nos limites de um conceito mais aberto, com base no qual a representação pudesse significar o "desdobramento de um volume, de um meio em várias dimensões, experiência produtora do seu próprio espaço" (Derrida, 2002, p. 157).

Deduz-se daí, que a arte precisa ser, para Artaud, sempre radicalmente original, sempre nascimento, sempre origem. O tema das origens acompanhava continuamente seu pensamento. Nele, entretanto, a problemática ganha uma conotação mais trágica, porque não se trata exatamente de reencontrar a origem do teatro: "... A dança / e por consequência o teatro / ainda não começaram a existir" (Artaud apud Derrida, 2002, p. 150). Isto se dá mais exatamente porque o teatro ocidental já teria 
nascido morto, teria se originado num parto através do qual se produziu imediata dissociação entre ele e sua "vis affirmativa" (Artaud apud Derrida, 2002, p. 151). E é em função dessa origem, como natimorto, que o teatro jamais pôde encontrar seu sentido verdadeiro. Sentido este que Artaud não pensa a partir de um idealismo abstrato, mas tomando como referência concreta o teatro do Oriente (em especial o teatro de Bali) e as manifestações culturais denominadas arcaicas, como aquelas que ele veio a conhecer no México.

Acrescente-se a isso, sua perspectiva de religação entre arte e vida, que o levou a considerar o tema das origens sob uma perspectiva mais ampla, além do próprio teatro. O reencontro com as origens, no caso do Ocidente, estaria vinculado, portanto, a um momento anterior à origem do teatro, quando a noção de arte separada da vida ainda não teria surgido. Trata-se de um retorno do teatro aos rituais mágicos, e toda problemática artaudiana se adensa neste ponto, já que suas referências apontam continuamente para os horizontes do impossível. E é precisamente no limiar do impossível que o teatro da crueldade é formulado, "pois só pode haver teatro a partir do momento em que realmente começa o impossível e em que a poesia que acontece em cena alimenta e aquece símbolos realizados" (Artaud, 1993, p. 22).

Esse caráter impossível de sua arte, associado ao dado da não realização do teatro da crueldade, bem como à falta de um corpus metodológico de trabalho, de uma sistematização objetiva da realização cênica, sempre foi o alvo predileto das críticas que a Artaud foram dirigidas, especialmente por parte daqueles que o rejeitam. E se, de um lado, é fato notório que Artaud aponta continuamente para metas difíceis ou impossíveis de serem atingidas; se ele realmente nunca realizou seu idealizado teatro da crueldade, e se ninguém jamais seria capaz de realizá-lo; por outro lado o homem Artaud, é importante lembrar, não foi um mito. E se o foi, como há teóricos que gostam de metaforizar (Martin Esslin, por exemplo), tratou-se de um mito que verdadeiramente encarnou, tragicamente existiu. E que em sua vida, este mito realizou teatro, realizou cinema, gerou incômodos, exerceu o grito, andou, cuspiu (inclusive nos pratos em que comeu), sangrou.

Artaud não é (somente) uma figura de linguagem, e não apenas falou de um teatro impossível, como igualmente fez teatros objetivamente possíveis. E não haverá dúvidas de que tudo aquilo da ordem do impossível que ele pensava, de um ou de outro modo, influiu diretamente no resultado objetivo, concreto e real das experiências artísticas das quais participou, como influiu naquilo que fez quem o ouviu ou leu; como continua a influir naquilo que fazemos atualmente, bem ou mal. A função do mito nunca foi a de se manter distante do mundo concreto e real. Ao contrário, o mito funciona atuando na realidade cotidiana, fornecendo-lhe sentidos. Como diz Hillman, fato e significado precisam andar juntos (Hillman, 1998, p. 17), e o impossível de Artaud sempre funcionou, acordando ou perguntando pelos sentidos, no possível de nossa arte.

Ainda será oportuno relembrar o modo como Jacques Derrida refletiu acerca da arte nos horizontes do impossível em Artaud:

Mas a ideia de um teatro sem representação, a ideia do impossível, se não nos ajuda a regular a prática teatral, permite-nos talvez pensar a sua origem, a véspera 
e o limite, pensar o teatro de hoje a partir da abertura da sua história e no horizonte da sua morte. A energia do teatro ocidental deixa-se deste modo rodear na sua possibilidade, que não é acidental, que é para toda a história do Ocidente um centro constitutivo e um lugar estruturante (Derrida, 2002, p. 174).

Não é à toa que as ideias de Artaud são, costumeiramente, qualificadas como proféticas. O centro turbulento de seus impossíveis jamais abandonou a aventura teatral que o sucedeu. Por sua influência direta ou por coincidências significativas, as questões que ele veio a tocar se tornaram pivô para grande parte das problematizações que emergiram ao final do século XX, e que nos acompanham nos dias atuais. Não haverá decerto nenhum tema por ele levantado que não tenha vindo à baila nos debates teatrais que o sucederam: A questão da singularidade do teatro, que remete à necessidade de uma linguagem que lhe seja própria e, consequentemente, no modo como pode ou deve dar-se sua relação com a literatura ${ }^{2}$; a problemática da representação, na economia teatral, frente à irrupção de novas formas de exercer a presença cênica, influenciadas especialmente pela performance e pelas experiências de fronteira entre as artes; as conexões complementares entre o teatro e a dança, como se ambos fossem perspectivas diversas de uma mesma expressão artística; a relação interdependente entre arte e vida, que vieram a se mostrar urgentes e fecundas para experiências diversas, do butoh ao teatro das fontes; a problemática do político no teatro, que quando ocupa o lugar da finalidade pode subjugar o teatral, tornando-o mera ferramenta ${ }^{3}$; o diálogo com as chamadas culturas arcaicas, bem como com as formas teatrais do Oriente, que vieram a se tornar um eixo privilegiado de pesquisa, no qual a antropologia teatral adquiriu significativa proeminência; enfim, a relação do teatro com o sagrado, que vem a colocar em pauta um questionamento fundamental sobre o estatuto do teatro e do sagrado na vida e na cultura. Esses questionamentos não podem nem devem receber uma reposta definitiva, mas sim permanecerem como problema permanente em nossa vida de artistas. E foi essa, possivelmente, uma das maiores contribuições que Artaud nos legou.

\footnotetext{
${ }^{2}$ Seria também importante fazer referência ao movimento inverso que, partindo da literatura, volta-se para o fenômeno da performance. É o caso de Paul Zumthor, que buscou compreender a literatura para além das formulações posteriores da escrita, tomando a poesia oral como referência (cf. Zumthor, 2007).

${ }^{3}$ Refiro-me especialmente às confrontações que Artaud travou com os surrealistas, em função da adesão do movimento à ideologia comunista.
} 


\section{Referências}

ARTAUD, Antonin. O pesa-nervos. Lisboa: Hiena, 1991.

. O Teatro e seu duplo. São Paulo: Martins Fontes, 1993.

DERRIDA, Jacques. A escritura e a diferença. São Paulo: Perspectiva, 2002.

ELIADE, Mircea. O sagrado e o profano. São Paulo: Martins Fontes, 1992. Mito e realidade. São Paulo: Perspectiva, 2004.

FELICIO, Vera Lucia. À procura da lucidez em Artaud. São Paulo: Perspectiva, 1996.

HILLMAN, James. O livro do puer: ensaios sobre o arquétipo do puer aeternus. São Paulo: Paulus, 1998.

OLSEN, Mark. As máscaras mutáveis do Buda dourado: ensaios sobre a dimensão espiritual da interpretação teatral. São Paulo: Perspectiva, 2004.

SAID, Edward W. Orientalismo. São Paulo: Companhia das Letras, 2007.

NUNES, Alexandre Silva. Ator, sator, satori: labor e torpor na arte de personificar. Goiânia: Editora UFG, 2012.

ZUMTHOR, Paul. Performance, recepção, leitura. São Paulo: Cosac Naify, 2007.

Recebido em: $18 / 10 / 2015$

Aprovado em: 21/04/2016 